\title{
The Deficit and the Public Interest
}





\section{The Deficit \\ and the Public Interest \\ The Search for Responsible Budgeting in the 1980s}

Joseph White and Aaron Wildavsky

UNIVERSITY OF CALIFORNIA PRESS

Berkeley Los Angeles London RUSSELL SAGE FOUNDATION New York 
University of California Press

Berkeley and Los Angeles, California

University of California Press, Ltd.

London, England

(C) 1989 by

The Russell Sage Foundation

\section{Library of Congress Cataloging-in-Publication Data}

White, Joseph, 1952-

The deficit and the public interest : the search for responsible budgeting in the 1980s / Joseph White and Aaron Wildavsky.

p. $\quad \mathbf{c m}$.

Bibliography: p.

Includes index.

ISBN 0-520-06533-6 (alk. paper)

1. Budget-United States. 2. Budget deficits-United States.

3. Government spending policy-United States. 1. Wildavsky, Aaron

B. II. Title.

HJ2051.W45 1989

$336.3^{\prime} 9^{\prime} 0973$ dc20

89-5122

CIP

Printed in the United States of America

123456789

The paper used in this publication meets the minimum requirements of American National Standard for Information Sciences-Permanence of Paper for Printed Library Materials, ANSI Z39.48-1984. 
For Michael J. White and Daniel K. Tenenberg 
